\title{
Bayesian Network Analysis for the Questionnaire Investigation on the Impression at Yoshiwara Shopping Street in Fuji City
}

\author{
Tsuyoshi Aburai \\ Tokushima University \\ Akane Okubo
NIHON University Junior College \\ Daisuke Suzuki \\ Fujisan Area Management Company \\ Kazuhiro Takeyasu \\ College of Business Administration, Tokoha University
}

\begin{abstract}
Shopping streets at local city in Japan became old and are generally declining. In this paper, we handle the area rebirth and/or regional revitalization of shopping street. We focus on Fuji city in Japan. Four big festivals are held at Fuji city. Many people visit these festivals including residents in that area. Therefore a questionnaire investigation to the residents and visitors is conducted during these periods in order to clarify residents and visitors' needs for the shopping street, and utilize them to the plan building of the area rebirth and/or regional revitalization of shopping street. There is a big difference between Fuji Shopping Street and Yoshiwara Shopping Street. Therefore we focus Yoshiwara Shopping Street in this paper. These are analyzed by using Bayesian Network. Sensitivity analysis is also conducted. As there are so many items, we focus on "The image of the surrounding area at this shopping street" and pick up former half and make sensitivity analysis in this paper. The analysis utilizing Bayesian Network enabled us to visualize the causal relationship among items. Furthermore, sensitivity analysis brought us estimating and predicting the prospective visitors. Sensitivity analysis is performed by back propagation method. These are utilized for constructing a much more effective and useful plan building. We have obtained fruitful results. To confirm the findings by utilizing the new consecutive visiting records would be the future works to be investigated.
\end{abstract}

Keywords: Fuji City, Area rebirth; Regional vitalization; festival; Bayesian Network; Back Propagation;

\section{INTRODUCTION}

Shopping streets at local city in Japan are generally declining. It is because most of them were built in the so-called "High Growth Period (1954-1973)". Therefore they became old and area rebirth and/or regional revitalization are required everywhere.

There are many papers published concerning area rebirth or regional revitalization. Inoue (2017) has pointed out the importance of tourism promotion. Ingu et al.(2017) developed the project of shutter art to Wakkanai Chuo shopping street in Hokkaido, Japan. Ohkubo (2017) has made a questionnaire research at Jigenji shopping street in Kagoshima Prefecture, Japan and analyzed the current condition and future issues. For about tourism, many papers are presented from many aspects as follows. 
Yoshida et al. designed and conducted a visitor survey on the spot, which used a questionnaire to investigate the activities of visitors to the Ueno district in Taito ward, Tokyo. Doi et al. analyzed the image of the Izu Peninsula as a tourist destination in their 2003 study "Questionnaire Survey on the Izu Peninsula." Kano conducted tourist behavior studies in Atami city in 2008, 2009, 2014 and in other years.

In this paper, we handle the area rebirth and/or regional revitalization of shopping street. We focus on Fuji city in Japan. Fuji city is located in Shizuoka Prefecture. Mt. Fuji is very famous all around the world and we can see its beautiful scenery from Fuji city, which is at the foot of Mt. Fuji. There are two big shopping street in Fuji city. One is Yoshiwara Shopping Street and another one is Fuji Shopping Street. They became old and building area rebirth and regional revitalization plan have started. Following investigation was conducted by the joint research group (Fuji Chamber of Commerce \& Industry, Fujisan Area Management Company, Katsumata Maruyama Architects, Kougakuin University and Tokoha University). The main project activities are as follows.

A. Investigation on the assets which are not in active use

B. Questionnaire Investigation to Entrepreneur

C. Questionnaire Investigation to the residents and visitors

After that, area rebirth and regional revitalization plan were built.

In this paper, we handle above stated C.

Four big festivals are held at Fuji city. Two big festivals are held at Yoshiwara Shopping Street and two big festivals at Fuji Shopping Street.

At Yoshiwara Shopping Street, Yoshiwara Gion Festival is carried out during June and Yoshiwara Shukuba (post-town) Festival is held during October. On the other hand, Kinoene Summer Festival is conducted during August and Kinoene Autumn Festival is performed during October at Fuji Shopping Street. Many people visit these festivals including residents in that area.

Therefore questionnaire investigation of $\mathrm{C}$ is conducted during these periods.

Finally, we have obtained 982 sheets (Yoshiwara district: 448, Fuji district: 534).

Basic statistical analysis and Bayesian Network analysis are executed based on that.

In this paper, a questionnaire investigation is executed in order to clarify residents and visitors' needs for the shopping street, and utilize them to the plan building of the area rebirth and/or regional revitalization of shopping street. There is a big difference between Fuji Shopping Street and Yoshiwara Shopping Street. Therefore we focus Yoshiwara Shopping Street in this paper. These are analyzed by using Bayesian Network. Sensitivity analysis is also conducted. As there are so many items, we focus on "The image of the surrounding area at this shopping street" and pick up former half and make sensitivity analysis in this paper. By that model, the causal relationship is sequentially chained by the characteristics of visitors, the purpose of visiting and the image of the surrounding area at this shopping street. The analysis utilizing Bayesian Network enabled us to visualize the causal relationship among items. Furthermore, sensitivity analysis brought us estimating and predicting the prospective visitors. Sensitivity analysis was conducted by back propagation method. 
Some interesting and instructive results are obtained.

The rest of the paper is organized as follows. Outline of questionnaire investigation is stated in section 2. In section 3, Bayesian Network analysis is executed which is followed by the sensitivity analysis in section 4 . Remarks is stated in section 5.

\section{OUTLINE AND THE BASIC STATISTICAL RESULTS OF THE QUESTIONNAIRE RESEARCH Outline of the Questionnaire Research}

A questionnaire investigation to the residents and visitors is conducted during these periods in order to clarify residents and visitors' needs for the shopping street, and utilize them to the plan building of the area rebirth and/or regional revitalization of shopping street. The outline of questionnaire research is as follows. Questionnaire sheet is attached in Appendix 1.

1. Scope of investigation : Residents and visitors who have visited four big festivals at Fuji city in Shizuoka Prefecture, Japan

2. Period : Yoshiwara Gion Festival: June 11,12/2016 Yoshiwara Shukuba (post-town) Festival: October 9/2016

Kinoene Summer Festival: August 6,7/2016

Kinoene Autumn Festival: October 15,16/2016

(3) Method : Local site, Dispatch sheet, Self writing

(4) Collection : Number of distribution 1400

Number of collection 982 (collection rate $70.1 \%$ )

Valid answer 982

\section{Basic Statistical Results}

Now, we show the main summary results by single variable.

\section{Characteristics of answers}

(1) Sex (Q7)

Male 55.6\%, Female 44.4\%

These are exhibited in Figure 1.

(2) Age (Q8)

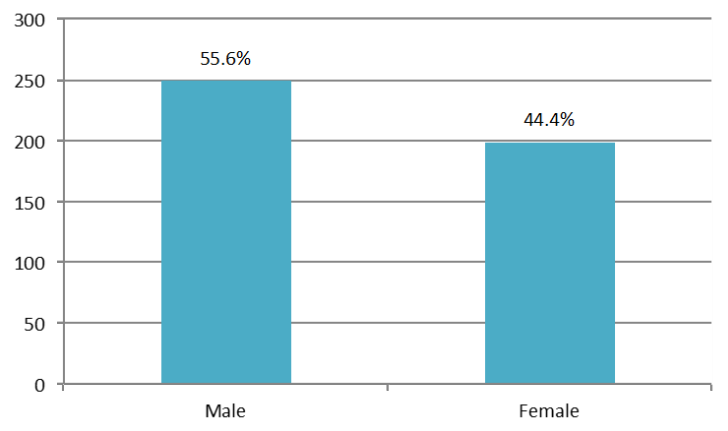

Figure 1. Sex (Q7)

10th $10.9 \%$, 20th $12.1 \%$, 30th $19.0 \%$, 40th $17.9 \%$, 50th $13.4 \%$, 60th $14.7 \%$, More than 70 $11.6 \%$

These are exhibited in Figure 2. 


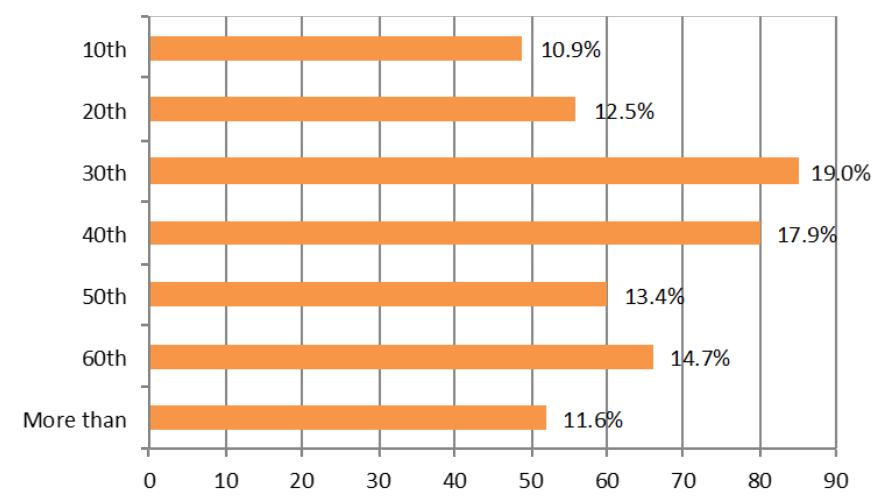

(3) Residence (Q9)

Figure 2. Age (Q8)

a. Fuji city $78.3 \%$, b. Fujinomiya city $6.9 \%$, c. Numazu city $4.5 \%$, d. Mishima city $1.3 \%$, e. Shizuoka city 2.9\%, F. Else (in Shizuoka Prefecture) 2.5\%, g. Outside of Shizuoka Prefecture $3.6 \%$

These are exhibited in Figure 3.

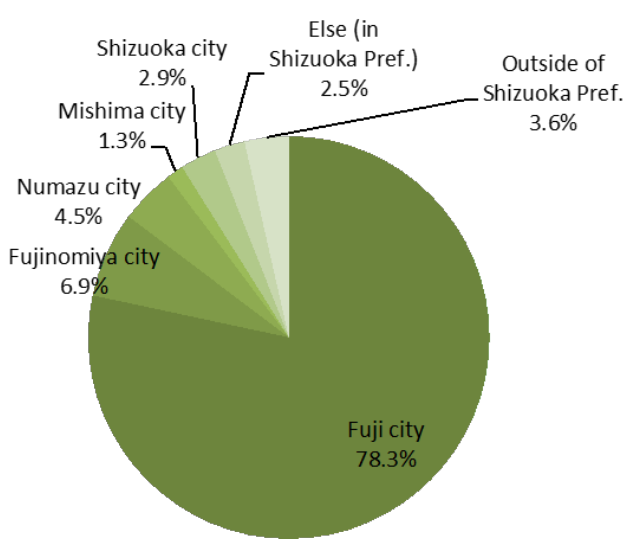

Figure 3. Residence (Q9)

\section{Summary results for the items used in Hypothesis Testin}

(1) How often do you come to this shopping street? (Q1)

Everyday $12.9 \%$, More than 1 time a week $15.6 \%$, More than 1 time a month $23.4 \%$, More than 1 time a year $37.3 \%$, First time $5.1 \%$, Not filled in $5.6 \%$

These are exhibited in Figure 4. 


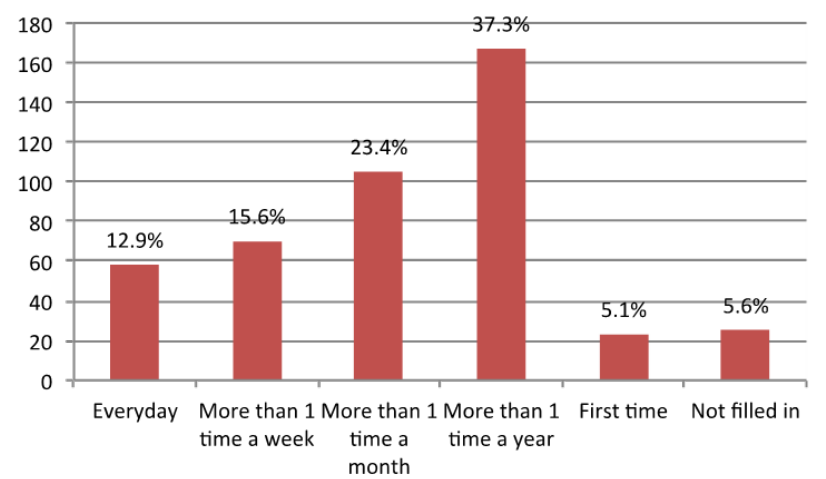

Figure 4. How often do you come to this shopping street? (Q1)

(2) What is the purpose of visiting here? (Q2)

Shopping 20.7\%, Eating and drinking 13.1\%, Business 7.5\%, Celebration, event 47.5\%, Leisure, amusement 1.5\%, miscellaneous 9.7\%

These are exhibited in Figure 5.

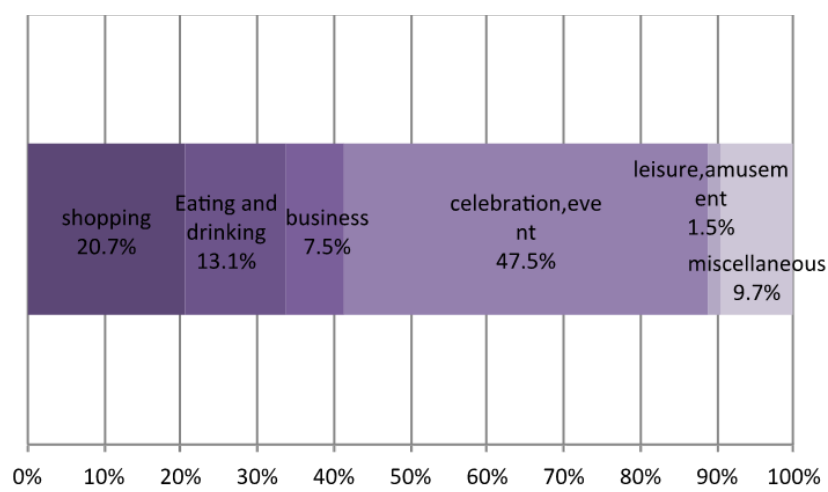

Figure 5. What is the purpose of visiting here? (Q2)

(3) How do you feel about the image of the surrounding area at this shopping street? (Q3)

Beautiful $51.9 \%$, Ugly $48.1 \%$, Of the united feeling there is $47.2 \%$,Scattered $52.8 \%$, Varied 40.0\%, Featureless $60.0 \%$, New $32.5 \%$,Historic $67.5 \%$,Full of nature $53.1 \%$,Urban $46.9 \%$, Cheerful 49.4\%, Gloomy 50.6\%,Individualistic 46.3\%,Conventional 53.7\%,Friendly 61.6\%, Unfriendly 38.4\%, Healed 54.2\%,Stimulated 45.8\%,Open 47.9\%,exclusive $52.1 \%$,Want to reside $45.1 \%$, Do not want to reside 54.9\%,Warm 62.6\%,Aloof 37.4\%,Fascinating 49.6\%,Not fascinating $50.4 \%$, Want to play $47.8 \%$,Want to examine deliberately $52.2 \%$, Lively $40.3 \%$,Calm $59.7 \%$, Atmosphere of urban 30.5\%,Atmosphere of rural area $69.5 \%$

These are exhibited in Figure 6. 


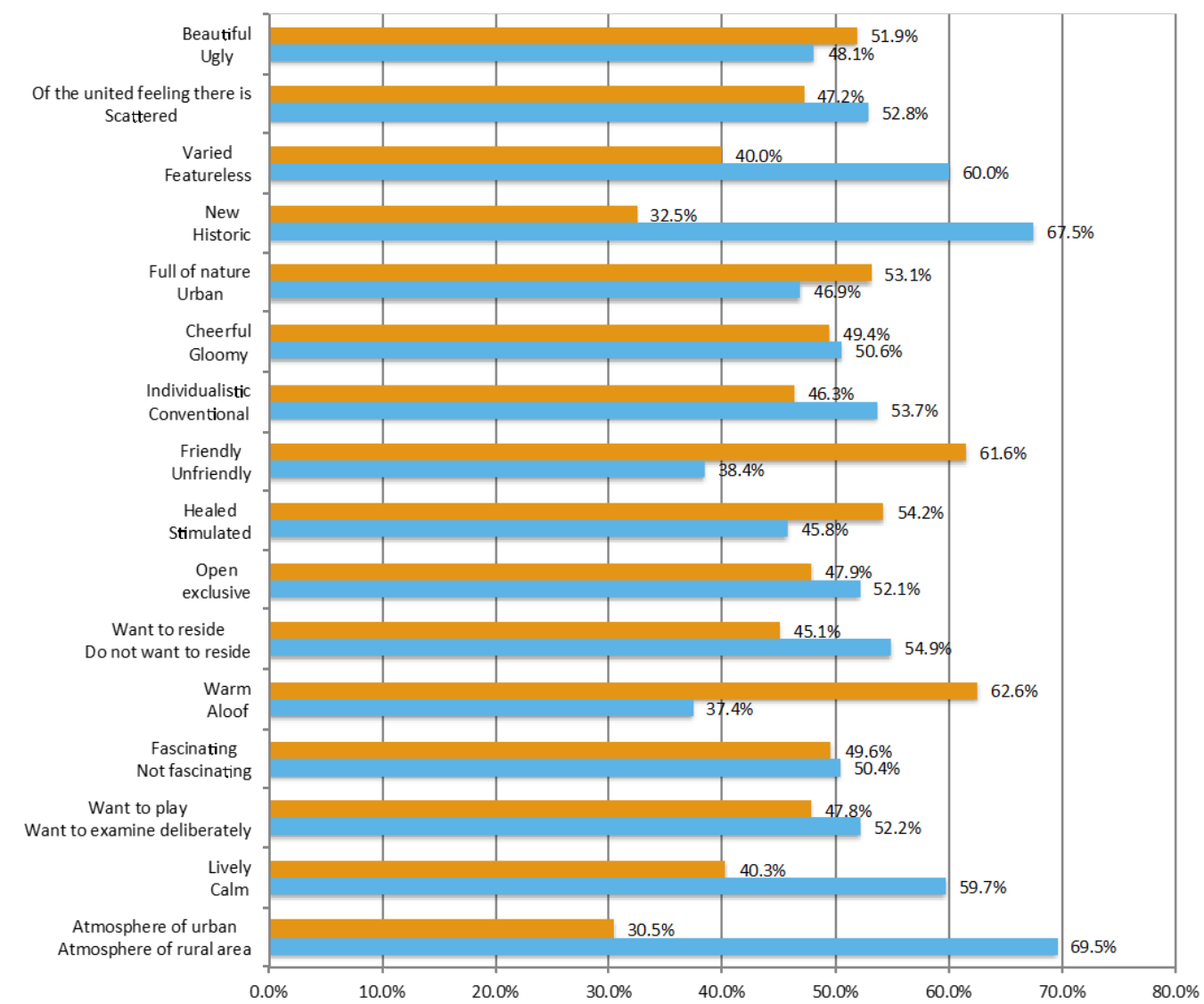

Figure 6. How do you feel about the image of the surrounding area at this shopping street? (Q3)

(4) There are many old building at the age of nearly 50 years. Do you think we can still use them? (Q4)

Can use it 38.6\%, Cannot use it 33.9\%, Have no idea 27.5\%

These are exhibited in Figure 7.

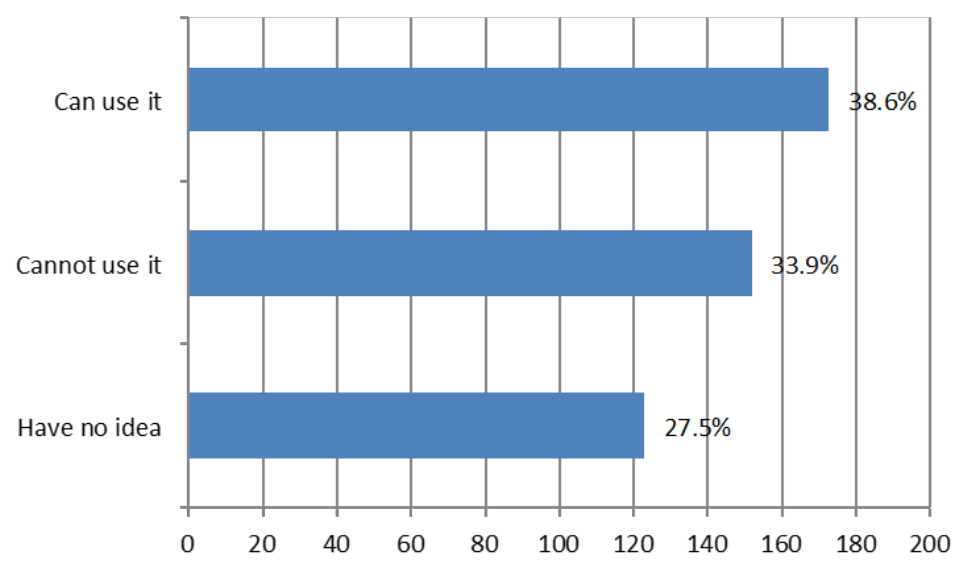

Figure 7. There are many old building at the age of nearly 50 years. Do you think we can still use them? (Q4)

\section{BAYESIAN NETWORK ANALYSIS}

In constructing Bayesian Network, it is required to check the causal relationship among groups of items.

Based on this, a model is built as is shown in Figure 8. 


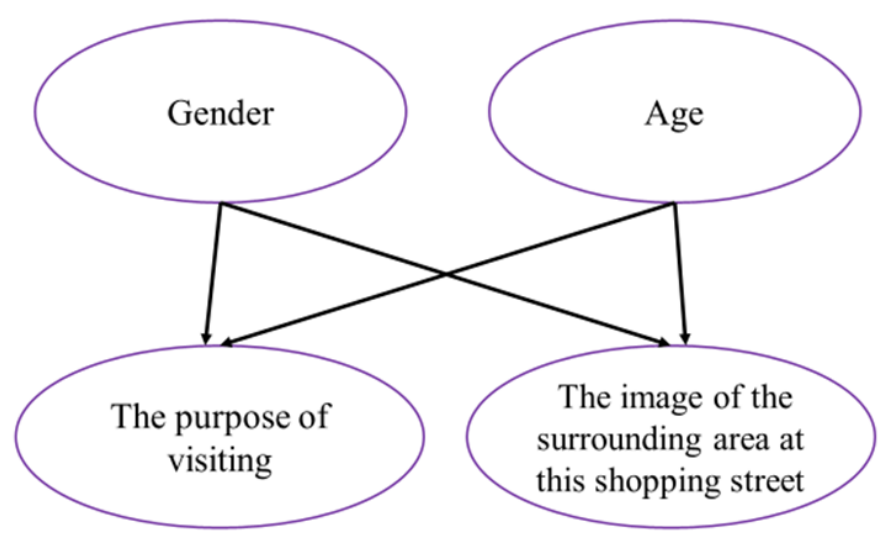

Figure 8. A Built Model

We used BAYONET software (http://www.msi.co.jp/BAYONET/). When plural nodes exist in the same group, it occurs that causal relationship is hard to set a priori. In that case, BAYONET system set the sequence automatically utilizing AIC standard. Node and parameter of Figure 8 are exhibited in Table 1.

Table 1. Node and Parameter

\begin{tabular}{|c|c|c|c|c|c|c|c|c|c|c|}
\hline \multirow{2}{*}{ Node } & \multicolumn{10}{|c|}{ Parameter } \\
\hline & 1 & 2 & 3 & 4 & 5 & 6 & 7 & 8 & 9 & 10 \\
\hline Gender & Male & Female & & & & & & & & \\
\hline Age & 10th & 20th & 30 th & 40th & 50 th & 60 th & $\begin{array}{c}\text { More } \\
\text { than } \\
70\end{array}$ & & & \\
\hline $\begin{array}{c}\text { The purpose of } \\
\text { visiting }\end{array}$ & $\begin{array}{l}\text { Shoppi } \\
\text { ng }\end{array}$ & $\begin{array}{c}\text { Eating } \\
\text { and } \\
\text { drinking }\end{array}$ & Business & $\begin{array}{l}\text { Celebr } \\
\text { ation } \\
\text { v } \\
\text { event }\end{array}$ & $\begin{array}{l}\text { Leisur } \\
\text { e, } \\
\text { amuse } \\
\text { ment }\end{array}$ & $\begin{array}{c}\text { miscel } \\
\text { laneo } \\
\text { us }\end{array}$ & & & & \\
\hline $\begin{array}{l}\text { The image of } \\
\text { the } \\
\text { surrounding } \\
\text { area at this } \\
\text { shopping } \\
\text { street }\end{array}$ & $\begin{array}{c}\text { Beautif } \\
\text { ul }\end{array}$ & Ugly & $\begin{array}{l}\text { Of the } \\
\text { united } \\
\text { feeling } \\
\text { there is }\end{array}$ & $\begin{array}{l}\text { Scatte } \\
\text { red }\end{array}$ & Varied & $\begin{array}{l}\text { Featur } \\
\text { eless }\end{array}$ & New & $\begin{array}{l}\text { Histor } \\
\text { ic }\end{array}$ & $\begin{array}{l}\text { Full of } \\
\text { nature }\end{array}$ & Urban \\
\hline
\end{tabular}

\begin{tabular}{|c|c|c|c|c|c|c|c|c|c|c|}
\hline \multirow{2}{*}{ Node } & \multicolumn{10}{|c|}{ Parameter } \\
\cline { 2 - 9 } & 11 & 12 & 13 & 14 & 15 & 16 & 17 & 18 & 19 & 20 \\
\hline $\begin{array}{c}\text { The image of } \\
\text { the } \\
\begin{array}{c}\text { surrounding } \\
\text { area at this } \\
\text { shopping } \\
\text { street }\end{array}\end{array}$ & $\begin{array}{c}\text { Cheerfu } \\
\mathrm{l}\end{array}$ & Gloomy & $\begin{array}{c}\text { Individuali } \\
\text { stic }\end{array}$ & $\begin{array}{c}\text { Conve } \\
\text { ntiona } \\
\mathrm{l}\end{array}$ & $\begin{array}{c}\text { Frien } \\
\text { dly }\end{array}$ & $\begin{array}{c}\text { Unfrie } \\
\text { ndly }\end{array}$ & $\begin{array}{c}\text { Heale } \\
\mathrm{d}\end{array}$ & $\begin{array}{c}\text { Stimul } \\
\text { ated }\end{array}$ & Open & $\begin{array}{c}\text { Exclus } \\
\text { ive }\end{array}$ \\
\hline
\end{tabular}




\begin{tabular}{|c|c|c|c|c|c|c|c|c|c|c|}
\hline \multirow{2}{*}{ Node } & \multicolumn{10}{|c|}{ Parameter } \\
\hline & 21 & 22 & 23 & 24 & 25 & 26 & 27 & 28 & 29 & 30 \\
\hline $\begin{array}{l}\text { The image of } \\
\text { the } \\
\text { surrounding } \\
\text { area at this } \\
\text { shopping } \\
\text { street }\end{array}$ & $\begin{array}{c}\text { Want to } \\
\text { reside }\end{array}$ & $\begin{array}{l}\text { Do not } \\
\text { want to } \\
\text { reside }\end{array}$ & Warm & Aloof & $\begin{array}{c}\text { Fascin } \\
\text { ating }\end{array}$ & $\begin{array}{c}\text { Not } \\
\text { fascin } \\
\text { ating }\end{array}$ & $\begin{array}{l}\text { Want } \\
\text { to } \\
\text { play }\end{array}$ & $\begin{array}{l}\text { Want } \\
\text { to } \\
\text { exami } \\
\text { ne } \\
\text { delibe } \\
\text { rately }\end{array}$ & Lively & Calm \\
\hline
\end{tabular}

\begin{tabular}{|c|c|c|}
\hline \multirow{2}{*}{ Node } & 31 & 32 \\
\cline { 2 - 3 } & & \\
\hline The image of \\
the \\
surrounding \\
$\begin{array}{c}\text { area at this } \\
\text { shopping street }\end{array}$ & Atmosphere of urban & Atmosphere of rural area \\
\hline
\end{tabular}

In the next section, sensitivity analysis is achieved by back propagation method. Back propagation method is conducted in the following method (Figure 9).

$$
\begin{aligned}
& \operatorname{Pr}(X=x)=(x)(x) \\
& (x)={ }_{u} P(x \mid U=u)_{U_{i}} U_{i} X \\
& (x)=Y_{Y_{j}}(u) \\
& Y_{j}(x) \\
& (x)=(x)_{k j} Y_{k} X(x) \\
& X U_{i}(u)={ }_{x}^{(x)} P(x \mid U)_{k i} U_{k} X\left(u_{k}\right)
\end{aligned}
$$

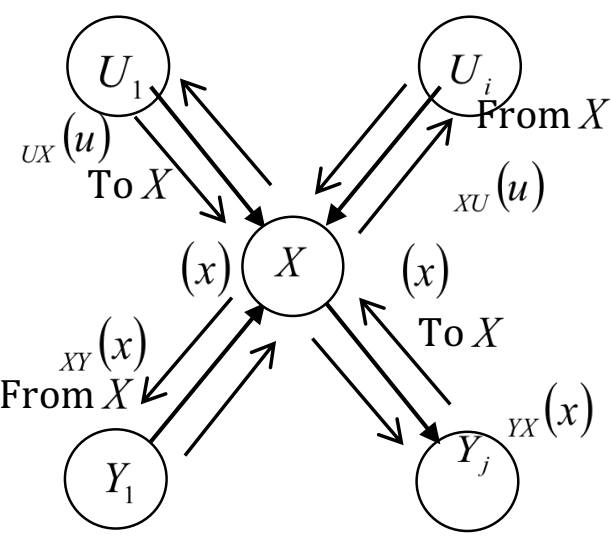

Figure 9. Back propagation method (Takeyasu et al., 2010)

\section{SENSITIVITY ANALYSIS}

Now, posterior probability is calculated by setting evidence as, for example, 1.0. Comparing Prior probability and Posterior probability, we can seek the change and confirm the preference or image of the surrounding area at this shopping street. We set evidence to all parameters. Therefore, the analysis volume becomes too large. In this paper, we focus on "The image of the surrounding area at this shopping street" and pick up latter half and make sensitivity analysis. We prepare another paper for the rest of them.

As stated above, we set evidence for each parameter, and the calculated posterior probability is exhibited in Appendix 2. The value of "Posterior probability - Prior probability" (we call this "Difference of probability" hereafter) is exhibited in Appendix 3. The sensitivity analysis is executed by mainly using this table.

Here, we classify each item by the strength of the difference of probability.

- Strong $(++,--)$ : Select major parameter of which absolute value of difference of probability is more than 0.05

- Medium $(+,-)$ : Select major parameter of which absolute value of difference of probability is more than 0.01 
- Weak: Else

In selecting items, negative value does not necessarily have distinct meaning, therefore we mainly pick up positive value in the case meaning is not clear.

Now we examine each for Strong and Medium case.

\section{Sensitively Analysis for "The image of the surrounding area at this shopping street}

(1) Setting evidence to "Healed"

After setting evidence to "Healed", the result is exhibited in Table 2.

Table 2. Setting evidence to "Healed" case

\begin{tabular}{|l|l|}
\hline Shopping & - \\
\hline Eating and drinking & - \\
\hline Of the united feeling there is & + \\
\hline Cheerful & + \\
\hline Individualistic & + \\
\hline Fascinating & + \\
\hline Want to play & + \\
\hline Lively & + \\
\hline Atmosphere of urban & + \\
\hline Male & - \\
\hline Female & + \\
\hline Age: 10 th & ++ \\
\hline Age: 20 th & + \\
\hline Age: 30 th & + \\
\hline Age: 40 th & + \\
\hline Age: 50 th & -- \\
\hline Age: 60 th & - \\
\hline Age: More than 70 & -- \\
\hline
\end{tabular}

We can observe that "Those who have an image of the surrounding area this shopping street as "Healed" had come under the image of the surrounding area at this shopping street as "Of the united feeling there is", "Cheerful", "Individualistic", "Fascinating", "Want to play", "Lively" or "Atmosphere of urban" of an age of "10th", "20th", "30th" or" 40th" in which the gender is "Female". (Strong part is indicated by bold font.)

(2) Setting evidence to "Stimulated"

After setting evidence to "Stimulated", the result is exhibited in Table 3.

Table 3. Setting evidence to "Stimulated" case

\begin{tabular}{|l|l|}
\hline Fascinating & - \\
\hline Want to play & - \\
\hline Lively & - \\
\hline Age: 10 th & -- \\
\hline Age: 20 th & -- \\
\hline Age: 50 th & + \\
\hline Age: 60 th & + \\
\hline Age: More than 70 & + \\
\hline
\end{tabular}

We can observe that "Those who have an image of the surrounding area at this shopping street as "Stimulated" had come by an age of " 50 th", "60th" or" More than 70 ". 
(3) Setting evidence to "Open"

After setting evidence to "Open", the result is exhibited in Table 4.

Table 4. Setting evidence to "Stimulated" case

\begin{tabular}{|l|l|}
\hline Male & + \\
\hline Female & - \\
\hline Age: 20th & + \\
\hline Age: 40 th & + \\
\hline Age: 50 th & - \\
\hline Age: 60th & + \\
\hline Age: More than 70 & - \\
\hline
\end{tabular}

We can observe that "Those who have an image of the surrounding area at this shopping street as "Open" had come by an age of "20th", "40th" or "60th" in which the gender is "Male".

(4) Setting evidence to "Exclusive"

After setting evidence to "Exclusive", the result is exhibited in Table 5.

Table 5. Setting evidence to "Exclusive" case

\begin{tabular}{|l|l|}
\hline Business & + \\
\hline Atmosphere of urban & - \\
\hline Male & - \\
\hline Female & + \\
\hline Age: 10 th & -- \\
\hline Age: 20 th & ++ \\
\hline Age: 30th & ++ \\
\hline Age: 40 th & - \\
\hline Age: 50th & - \\
\hline Age: 60 th & - \\
\hline Age: More than 70 & - \\
\hline
\end{tabular}

We can observe that "Those who have an image of the surrounding area at this shopping street as "Exclusive" had come with the purpose of visiting for "Business" of an age of "20th" or "30th" in which the gender is "Female".

(5) Setting evidence to "Want to reside"

After setting evidence to "Want to reside", the result is exhibited in Table 6.

Table 6. Setting evidence to "Want to reside" case

\begin{tabular}{|l|l|}
\hline Male & + \\
\hline Female & - \\
\hline Age: 10 th & - \\
\hline Age: 20 th & + \\
\hline Age: 40 th & + \\
\hline Age: 50 th & - \\
\hline Age: 60 th & - \\
\hline Age: More than 70 & ++ \\
\hline
\end{tabular}

We can observe that "Those who have an image of the surrounding area at this shopping street as "Want to reside" had come by an age of "20th","40th" or "More than 70" in which the gender is "Male". 
(6) Setting Evidence to "Do not want to reside"

After setting evidence to "Do not want to reside", the result is exhibited in Table 7.

Table 7. Setting evidence to "Do not want to reside" case

\begin{tabular}{|l|l|}
\hline Business & - \\
\hline Lively & + \\
\hline Male & + \\
\hline Female & - \\
\hline Age: 10 th & ++ \\
\hline Age: 20 th & - \\
\hline Age: 30 th & + \\
\hline Age: 40 th & - \\
\hline Age: 50 th & - \\
\hline Age: 60 th & ++ \\
\hline Age: More than 70 & -- \\
\hline
\end{tabular}

We can observe that "Those who have an image of the surrounding area at this shopping street as "Do not want to reside" had come under the image of the surrounding area at this shopping street as "Lively" of an age of "10th", "30th" or "60th" in which the gender is "Male".

(7) Setting Evidence to "Warm"

After setting evidence to "Warm", the result is exhibited in Table 8.

Table 8. Setting evidence to "Warm" case

\begin{tabular}{|l|l|}
\hline Eating and drinking & - \\
\hline Leisure, amusement & - \\
\hline Male & - \\
\hline Female & + \\
\hline Age: 10 th & + \\
\hline Age: 40 th & ++ \\
\hline Age: 50 th & -- \\
\hline Age: 60th & - \\
\hline Age: More than 70 & - \\
\hline
\end{tabular}

We can observe that "Those who have an image of the surrounding area at this shopping street as "Warm" had come by an age of "10th" or "40th" in which the gender is "Female".

(8) Setting evidence to "Aloof"

After setting evidence to "Aloof", the result is exhibited in Table 9.

Table 9. Setting evidence to "Aloof" case

\begin{tabular}{|l|l|}
\hline Age: 30 th & - \\
\hline Age: 50th & + \\
\hline Age: 60th & ++ \\
\hline Age: More than 70 & -- \\
\hline
\end{tabular}

We can observe that "Those who have an image of the surrounding area at this shopping street as "Aloof" had come by an age of " 50 th" or "60th".

(9) Setting evidence to "Fascinating"

After setting evidence to "Fascinating", the result is exhibited in Table 10. 
Table 10. Setting evidence to "Fascinating" case

\begin{tabular}{|l|l|}
\hline Shopping & - \\
\hline Eating and drinking & - \\
\hline Beautiful & + \\
\hline Ugly & - \\
\hline Of the united feeling there is & + \\
\hline Scattered & - \\
\hline Varied & + \\
\hline Featureless & - \\
\hline Urban & - \\
\hline Cheerful & + \\
\hline Gloomy & - \\
\hline Individualistic & + \\
\hline Friendly & + \\
\hline Healed & + \\
\hline Stimulated & - \\
\hline Want to play & + \\
\hline Lively & + \\
\hline Male & - \\
\hline Female & + \\
\hline Age: $10^{\text {th }}$ & ++ \\
\hline Age: $20^{\text {th }}$ & ++ \\
\hline Age: $40^{\text {th }}$ & - \\
\hline Age: $50^{\text {th }}$ & -- \\
\hline Age: $60^{\text {th }}$ & -- \\
\hline Age: More than 70 & - \\
\hline
\end{tabular}

We can observe that "Those who have an image of the surrounding area at this shopping street as "Fascinating" had come under the image of the surrounding area at this shopping street as "Beautiful", "Of the united feeling there is", "Varied"," Cheerful", "Individualistic", "Friendly", "Healed", "Want to play" or "Lively" of an age of "10th" or "20th" in which the gender is "Female".

(10) Setting evidence to "Not fascinating"

After setting evidence to "Not fascinating", the result is exhibited in Table 11. 
Table 11. Setting evidence to "Not fascinating" case

\begin{tabular}{|l|l|}
\hline Of the united feeling there is & - \\
\hline Featureless & + \\
\hline Urban & + \\
\hline Cheerful & - \\
\hline Gloomy & + \\
\hline Individualistic & - \\
\hline Want to play & - \\
\hline Want to examine deliberately & + \\
\hline Lively & - \\
\hline Atmosphere of urban & - \\
\hline Female & + \\
\hline Age: $10^{\text {th }}$ & -- \\
\hline Age: $20^{\text {th }}$ & - \\
\hline Age: $30^{\text {th }}$ & ++ \\
\hline Age: $40^{\text {th }}$ & - \\
\hline Age: $50^{\text {th }}$ & - \\
\hline Age: $60^{\text {th }}$ & ++ \\
\hline Age: More than 70 & + \\
\hline
\end{tabular}

We can observe that "Those who have an image of the surrounding area at this shopping street as "Not fascinating" had come under the image of the surrounding area at this shopping street as "Featureless", "Urban", "Gloomy" or "Want to examine deliberately" of an age of an age of "30th", "60th" or "More than 70" in which the gender is "Female".

(11) Setting evidence to "Want to play"

After setting evidence to "Want to play", the result is exhibited in Table 12. 
Table 12. Setting evidence to "Want to play" case

\begin{tabular}{|l|l|}
\hline Shopping & - \\
\hline Eating and drinking & - \\
\hline Business & - \\
\hline Ugly & - \\
\hline Of the united feeling there is & + \\
\hline Scattered & - \\
\hline Urban & - \\
\hline Cheerful & + \\
\hline Gloomy & - \\
\hline Individualistic & + \\
\hline Friendly & + \\
\hline Healed & + \\
\hline Stimulated & - \\
\hline Fascinating & + \\
\hline Not fascinating & - \\
\hline Lively & + \\
\hline Calm & - \\
\hline Atmosphere of urban & + \\
\hline Atmosphere of rural area & - \\
\hline Male & + \\
\hline Female & - \\
\hline Age: $10^{\text {th }}$ & ++ \\
\hline Age: $20^{\text {th }}$ & ++ \\
\hline Age: $30^{\text {th }}$ & - \\
\hline Age: $40^{\text {th }}$ & + \\
\hline Age: $50^{\text {th }}$ & -- \\
\hline Age: $60^{\text {th }}$ & -- \\
\hline Age: More than 70 & -- \\
\hline
\end{tabular}

We can observe that "Those who have an image of the surrounding area at this shopping street as "Want to play" had come under the image of the surrounding area at this shopping street as "Of the united feeling there is", "Cheerful", "Individualistic", "Friendly", "Healed", "Fascinating", "Lively" or "Atmosphere of urban" of an age of "10th", "20th" or "40th" in which the gender is "Male".

(12) Setting evidence to "Want to examine deliberately" After setting evidence to "Want to examine deliberately", the result is exhibited in Table 13. 
Table 13. Setting evidence to "Want to examine deliberately" case

\begin{tabular}{|l|l|}
\hline Shopping & + \\
\hline Eating and drinking & - \\
\hline Ugly & + \\
\hline Of the united feeling there is & - \\
\hline Gloomy & + \\
\hline Individualistic & - \\
\hline Fascinating & - \\
\hline Not fascinating & + \\
\hline Lively & - \\
\hline Atmosphere of urban & - \\
\hline Male & - \\
\hline Female & + \\
\hline Age: $10^{\text {th }}$ & -- \\
\hline Age: $20^{\text {th }}$ & - \\
\hline Age: $30^{\text {th }}$ & - \\
\hline Age: $40^{\text {th }}$ & + \\
\hline Age: $50^{\text {th }}$ & -- \\
\hline Age: $60^{\text {th }}$ & ++ \\
\hline Age: More than 70 & ++ \\
\hline
\end{tabular}

We can observe that "Those who have an image of the surrounding area at this shopping street as "Want to examine deliberately" had come with the purpose of visiting for "Shopping" under the image of the surrounding area at this shopping street as "Ugly", "Gloomy" or "Not fascinating" of an age of "40th", "60th" or "More than 70" in which the gender is "Female".

(13) Setting evidence to "Lively"

After setting evidence to "Lively", the result is exhibited in Table 14. 
Table 14. Setting evidence to "Lively" case

\begin{tabular}{|l|l|}
\hline Shopping & - \\
\hline Business & - \\
\hline Beautiful & + \\
\hline Ugly & - \\
\hline Of the united feeling there is & + \\
\hline Scattered & - \\
\hline Varied & + \\
\hline Cheerful & + \\
\hline Gloomy & - \\
\hline Individualistic & + \\
\hline Friendly & + \\
\hline Healed & + \\
\hline Stimulated & - \\
\hline Fascinating & + \\
\hline Not fascinating & - \\
\hline Want to play & + \\
\hline Want to examine deliberately & - \\
\hline Atmosphere of urban & + \\
\hline Atmosphere of rural area & - \\
\hline Male & + \\
\hline Female & - \\
\hline Age: 10th & ++ \\
\hline Age: 20th & ++ \\
\hline Age: 30th & - \\
\hline Age: 40th & -- \\
\hline Age: 50th & -- \\
\hline Age: 60th & -- \\
\hline Age: More than 70 & - \\
\hline
\end{tabular}

We can observe that "Those who have an image of the surrounding area at this shopping street as "Lively" had come under the image of the surrounding area at this shopping street as "Beautiful", "Of the united feeling there is", "Varied", "Cheerful", "Individualistic", "Friendly", "Healed", "Fascinating", "Want to play", or "Atmosphere of urban" of an age of "10th" or "20th" in which the gender is "Male".

(14) Setting evidence to "Calm"

After setting evidence to "Calm", the result is exhibited in Table 15. 
Table 15. Setting evidence to "Calm" case

\begin{tabular}{|l|l|}
\hline Shopping & + \\
\hline Leisure, amusement & - \\
\hline Of the united feeling there is & - \\
\hline Cheerful & - \\
\hline Individualistic & - \\
\hline Fascinating & - \\
\hline Not fascinating & + \\
\hline Want to play & - \\
\hline Want to examine deliberately & + \\
\hline Atmosphere of urban & - \\
\hline Male & - \\
\hline Female & + \\
\hline Age: 10 th & -- \\
\hline Age: 20 th & -- \\
\hline Age: 30 th & ++ \\
\hline Age: 50 th & + \\
\hline Age: 60 th & + \\
\hline Age: More than 70 & ++ \\
\hline
\end{tabular}

We can observe that "Those who have an image of the surrounding area at this shopping street as "Calm" had come with the purpose of visiting for "Shopping" under the image of the surrounding area at this shopping street as "Not fascinating", or "Want to examine deliberately" of an age of "30th", "50th", "60th" or "More than 70" in which the gender is "Female".

(15) Setting evidence to "Atmosphere of urban"

After setting evidence to "Atmosphere of urban", the result is exhibited in Table 16.

Table 16. Setting evidence to "Atmosphere of urban" case

\begin{tabular}{|l|l|}
\hline Business & - \\
\hline Cheerful & + \\
\hline Want to play & + \\
\hline Lively & + \\
\hline Male & + \\
\hline Female & - \\
\hline Age: 10 th & ++ \\
\hline Age: 20 th & - \\
\hline Age: 40 th & - \\
\hline Age: 50 th & - \\
\hline Age: 60th & - \\
\hline Age: More than 70 & ++ \\
\hline
\end{tabular}

We can observe that "Those who have an image of the surrounding area at this shopping street as "Atmosphere of urban" had come under the image of the surrounding area at this shopping street as "Cheerful", "Want to play" or "Lively" of an age of "10th" or "More than 70" in which the gender is "Male".

(16) Setting evidence to "Atmosphere of rural area"

After setting evidence to "Atmosphere of rural area", the result is exhibited in Table 17. 
Table 17. Setting evidence to "Atmosphere of rural area" case

\begin{tabular}{|l|l|}
\hline Business & + \\
\hline Of the united feeling there is & - \\
\hline Cheerful & - \\
\hline Individualistic & - \\
\hline Friendly & - \\
\hline Fascinating & - \\
\hline Not fascinating & + \\
\hline Want to play & - \\
\hline Want to examine deliberately & + \\
\hline Lively & - \\
\hline Male & - \\
\hline Female & + \\
\hline Age: 10 th & - \\
\hline Age: 40th & - \\
\hline Age: 50th & ++ \\
\hline Age: 60th & ++ \\
\hline Age: More than 70 & + \\
\hline
\end{tabular}

We can observe that "Those who have an image of the surrounding area at this shopping street as "Atmosphere of rural area" had come with the purpose of visiting for "Business" under the image of the surrounding area at this shopping street as "Not fascinating" or "Want to examine deliberately" of an age of "50th", "60th" or "More than 70" in which the gender is "Female".

\section{REMARKS}

The Results for Bayesian Network Analysis are as follows.

In the Bayesian Network Analysis, model was built under the examination of the causal relationship among items. Sensitively Analysis was conducted after that. The main result of sensitively analysis is as follows.

We can observe that "Those who have an image of the surrounding area at this shopping street as "Healed" had come under the image of the surrounding area at this shopping street as "Of the united feeling there is", "Cheerful", "Individualistic", "Fascinating", "Want to play", "Lively" or "Atmosphere of urban" of an age of "10th", "20th", "30th" or"40th" in which the gender is "Female".

We can observe that "Those who have an image of the surrounding area at this shopping street as "Fascinating" had come under the image of the surrounding area at this shopping street as "Beautiful", "Of the united feeling there is", "Varied"," Cheerful", "Individualistic", "Friendly", "Healed", "Want to play" or "Lively" of an age of "10th" or "20th" in which the gender is "Female".

We can observe that "Those who have an image of the surrounding area at this shopping street as "Want to play" had come under the image of the surrounding area at this shopping street as "Of the united feeling there is", "Cheerful", "Individualistic", "Friendly", "Healed", "Fascinating", "Lively" or "Atmosphere of urban" of an age of "10th", "20th" or "40th" in which the gender is "Male".

We can observe that "Those who have an image of the surrounding area at this shopping street as "Want to examine deliberately" had come with the purpose of visiting for "Shopping" under the image of the surrounding area at this shopping street as "Ugly", "Gloomy" or "Not fascinating" of an age of "40th", "60th" or "More than 70" in which the gender is "Female". 
We can observe that "Those who have an image of the surrounding area at this shopping street as "Lively" had come under the image of the surrounding area at this shopping street as "Beautiful", "Of the united feeling there is", "Varied", "Cheerful", "Individualistic", "Friendly", "Healed", "Fascinating", "Want to play", or "Atmosphere of urban" of an age of "10th" or "20th" in which the gender is "Male".

We can observe that "Those who have an image of the surrounding area this shopping street as "Atmosphere of rural area" had come with the purpose of visiting for "Business" under the image of the surrounding area at this shopping street as "Not fascinating" or "Want to examine deliberately" of an age of "50th", "60th" or "More than 70" in which the gender is "Female".

\section{ACKNOWLEDGEMENTS}

The authors are grateful to all those who supported us for answering the questionnaire investigation.

\section{References}

Inoue, Akiko,. Changes in Local Communities Brought by Municipal Mergers : From the Viewpoint of Tourism Promotion as the Main Industry. Bulletin of the Faculty of Regional Development Studies, Otemon Gakuin University, 2017, 2, p.1-32

Ingu, Shuzo Uemura, Miki Uchida, Yuka Omiya, Misa Miura, Taiki Hironori, Hironori,. A study on the application of geothermal power generation to local revitalization in Obama Town, Unzen City: in consideration of futurability in Obama, Environmental Science Research, Nagasaki University, 2017, 20(1), p.51-63.

Kotani, Akihiro,. The implementation report of the Machi-lab shutter art project, Bulletin of Wakkanai Hokusei Gakuen University, 2017, (17), p.207-218.

Ohkubo Yukio,. Current status and problems in Jigenji-dori shopping area : from a consumer questionnaire, Bulletin of Local Research, Kagoshima International University, 2017, 44(2), p.1 -15.

Shioya Hideo,. Overview and application of tourism statistics: Analysis using statistical survey on overnight travels, Journal of Economic Structures 17(1-2), 2009, p.16-29.

Japan Tourism Agency,. Research study on economic impacts of tourism in Japan 2013, 2015, p.3.

Yoshida Ituki,. Consideration on the Characteristic of Visitors' Activity and the Research Method for Tourist Visitors in Urban Areas, 2009.

Doi Hideji., Evaluation of policies to build tourist destinations and statistical analysis, Nippon Hyoron Sha, 2009.

https://www.jnto.go.jp/eng/location/rtg/pdf/pg-410.pdf\#search='Izupeninsula'

http://www.kawazu-onsen.com/eng/

Atami city,. 2014 Survey of Tourist Behavior, 2015.

Kano, Michiko,. Characteristic analysis of Atami tourists: Reconsideration based on data add and modify, Shizuoka Economic Research, 2011, 16 (2), p. 61-78.

\section{APPENDIX 1 \\ Questionnaire Sheet about the Image Around the Shopping Street}

The authors are grateful to all those who supported us for answering the questionnaire investigation.

1. How often do you come to this shopping street?

a. Everyday b. ( ) times a week c. ( ) times a month d. ( ) times a year

e. miscellaneous (

2. What is the purpose of visiting here? (Plural answers allowed)

a. shopping b. eating and drinking c. business d. celebration、 event e. leisure, amusement

f. miscellaneous ( 
3. How do you feel about the image of the surrounding area at this shopping street? Select the position

\begin{tabular}{|c|c|c|c|c|c|c|}
\hline Beautiful & - & - & - & - & - & Ugly \\
\hline $\begin{array}{l}\text { Of the united } \\
\text { feeling there is }\end{array}$ & - & - & - & - & - & Scattered \\
\hline Varied & - & - & • & - & - & Featureless \\
\hline New & - & - & - & - & - & Historic \\
\hline Full of nature & $\cdot$ & $\cdot$ & - & - & $\cdot$ & Urban \\
\hline Cheerful & $\cdot$ & $\cdot$ & $\cdot$ & $\cdot$ & $\cdot$ & Gloomy \\
\hline Individualistic & - & $\cdot$ & - & - & - & Conventional \\
\hline Friendly & - & $\cdot$ & - & - & - & Unfriendly \\
\hline Healed & $\cdot$ & $\cdot$ & $\cdot$ & $\cdot$ & $\cdot$ & Stimulated \\
\hline Open & - & - & - & $\cdot$ & - & exclusive \\
\hline Want to reside & - & • & - & - & - & $\begin{array}{l}\text { Do not want to } \\
\text { reside }\end{array}$ \\
\hline Warm & $\cdot$ & - & - & $\cdot$ & - & Aloof \\
\hline Fascinating & $\cdot$ & - & $\cdot$ & - & - & Not fascinating \\
\hline Want to play & - & - & - & - & - & $\begin{array}{l}\text { Want to examine } \\
\text { deliberately }\end{array}$ \\
\hline Lively & $\cdot$ & $\cdot$ & $\cdot$ & $\cdot$ & $\cdot$ & Calm \\
\hline $\begin{array}{r}\text { Atmosphere of } \\
\text { urban }\end{array}$ & - & - & - & - & - & $\begin{array}{l}\text { Atmosphere of rural } \\
\text { area }\end{array}$ \\
\hline
\end{tabular}

4. There are many old building at the age of nearly 50 years. Do you think we can still use them?

a. Can use it b. Cannot use it c. Have no idea

5. Is there any functions or facilities that will be useful?

\section{Comments}

7. Sex

a. Male b. Female 


\section{Age}

a.10th b.20th c.30th d.40th e.50th f.6th g. More than70

9. Residence

a. Fuji City b. Fujinomiya City c. Numazu City d. Mishima City e. Shizuoka City f. Miscellaneous in Shizuoka Prefecture g. Outside of Shizuoka Prefecture [ 
Aburai, T., Okubo, A., Suzuki, D., \& Takeyasu, K. (2018). Bayesian Network Analysis for the Questionnaire Investigation on the Impression at Yoshiwara Shopping Street in Fuji City. Archives of Business Research, 6(5), 1-25.

\section{Calculated posterior probability}

\section{APPENDIX 2}

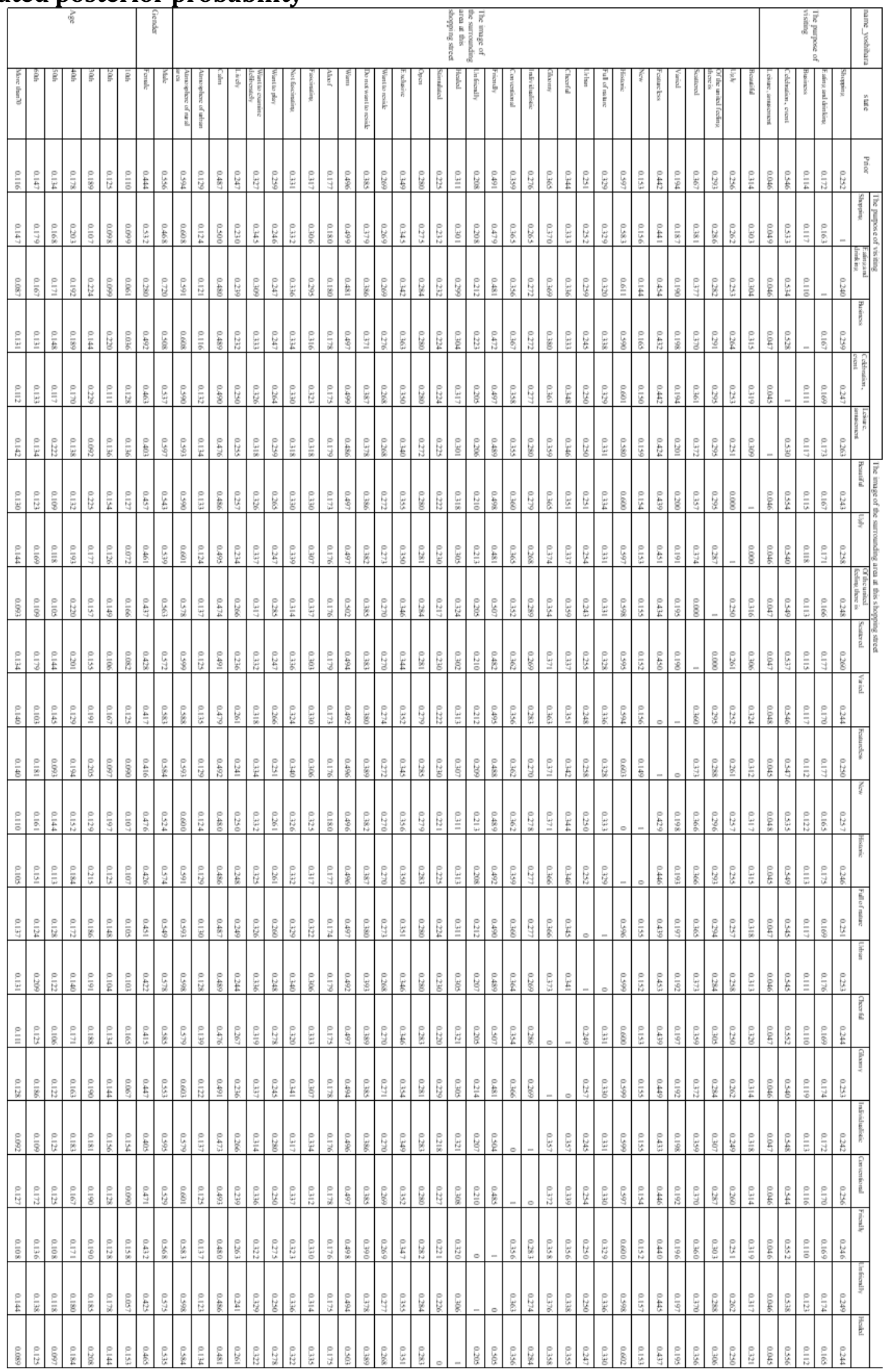




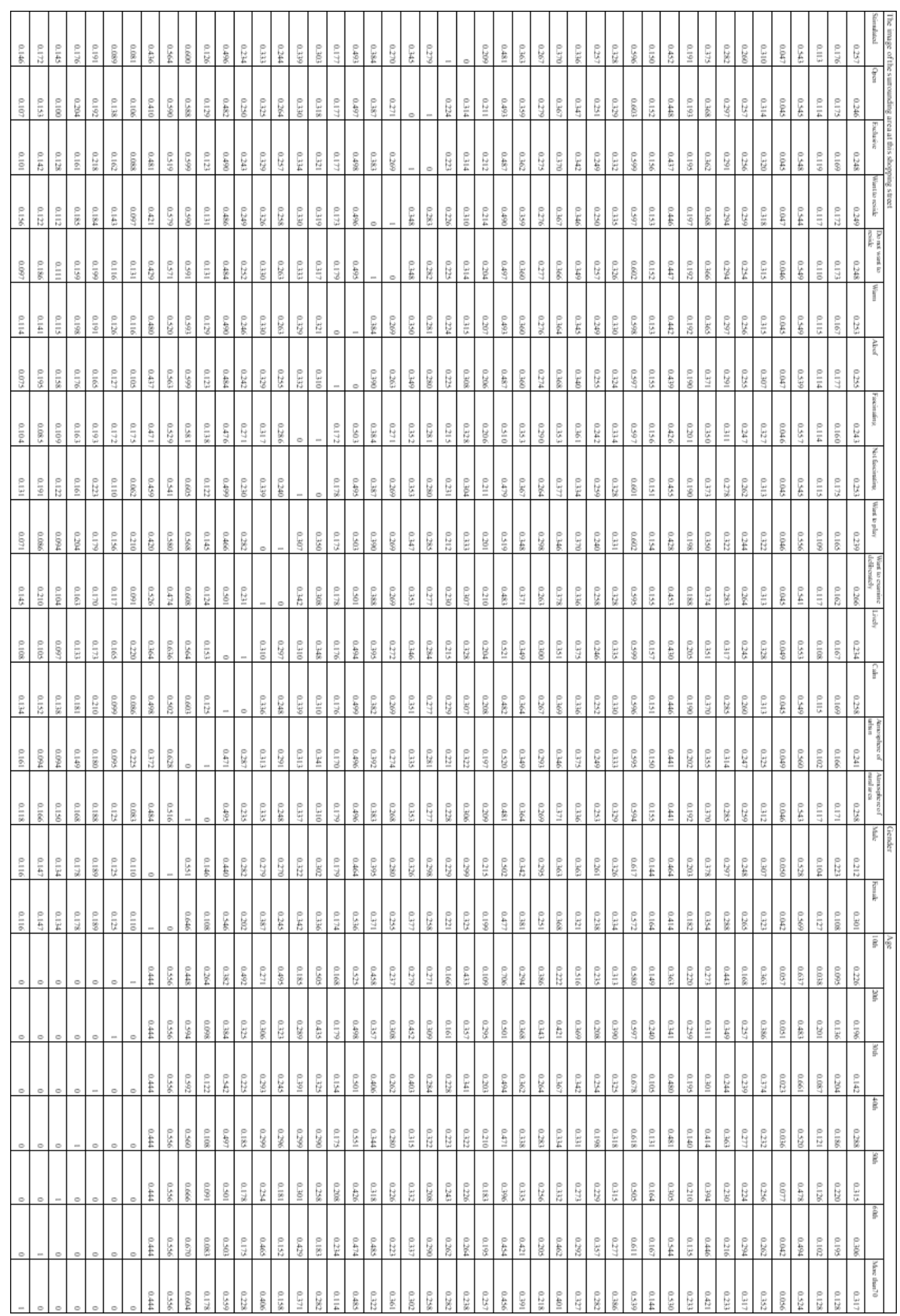


Aburai, T., Okubo, A., Suzuki, D., \& Takeyasu, K. (2018). Bayesian Network Analysis for the Questionnaire Investigation on the Impression at Yoshiwara Shopping Street in Fuji City. Archives of Business Research, 6(5), 1-25.

\section{Difference of probability}

\section{APPENDIX 3}

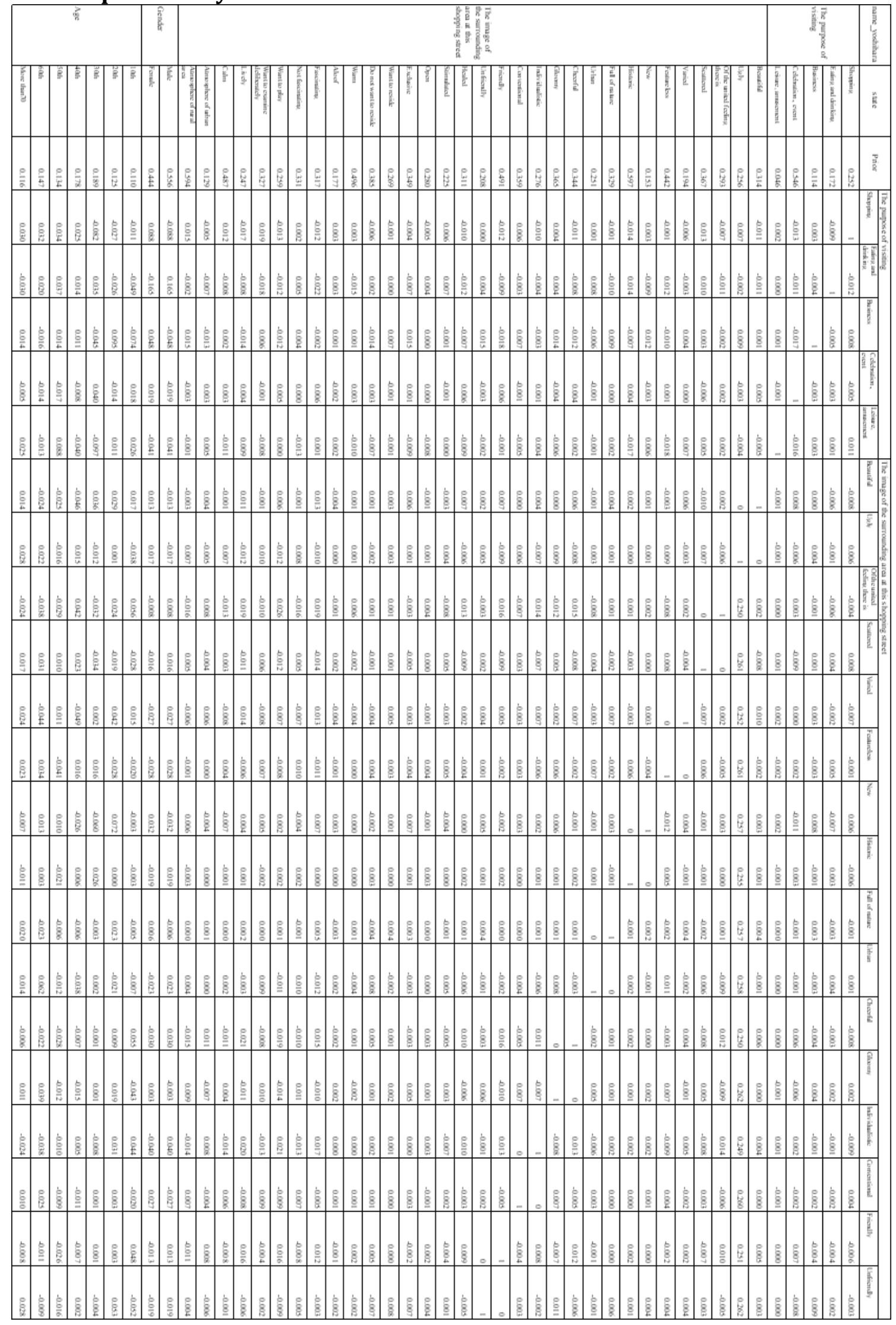




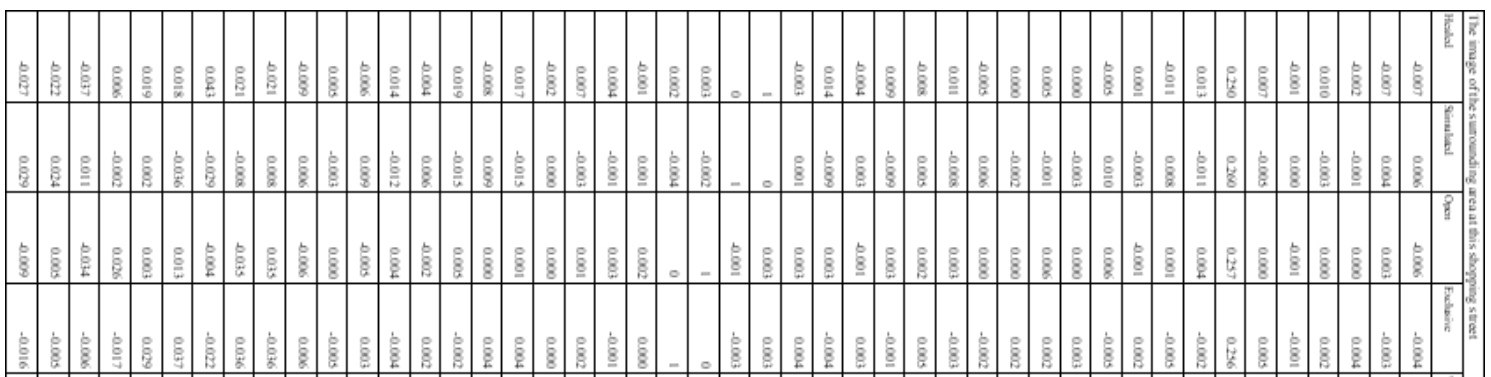

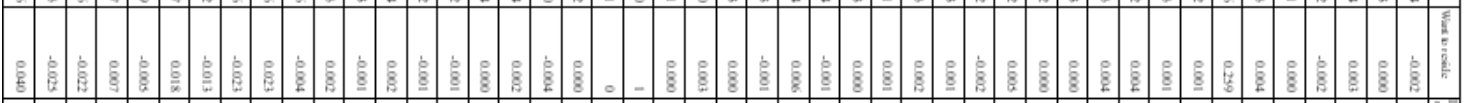

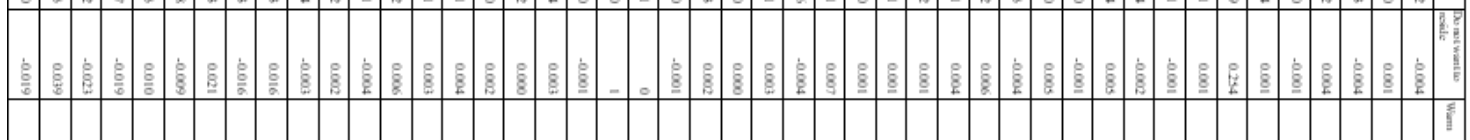

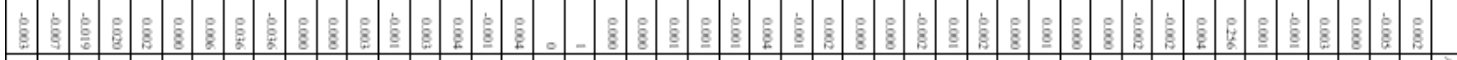

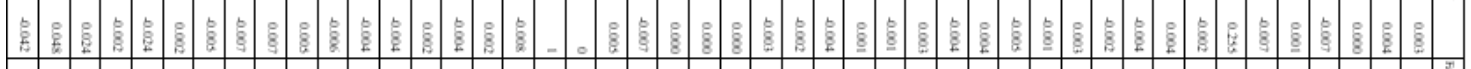

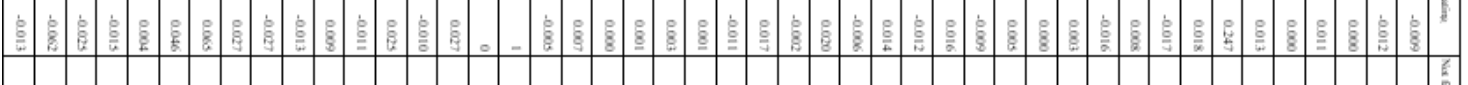

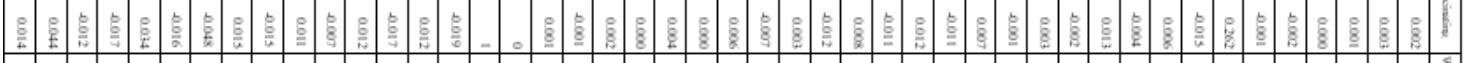

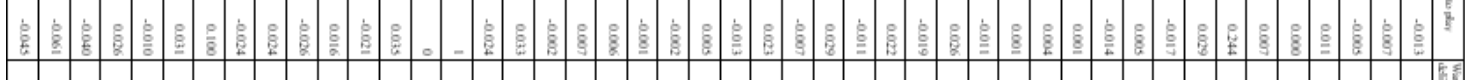

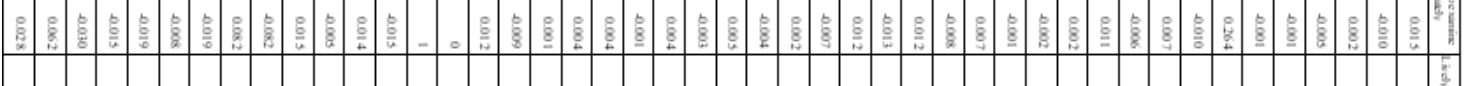

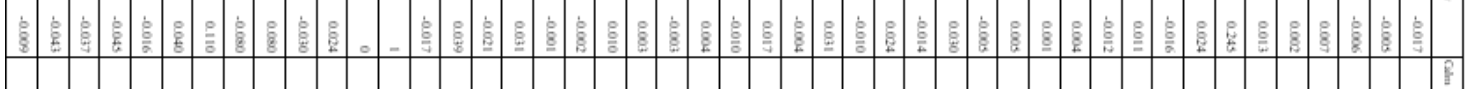

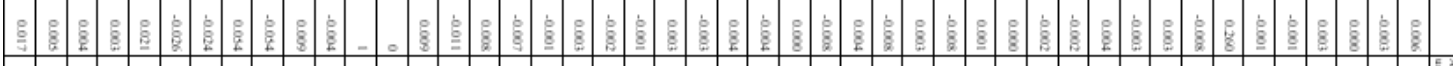

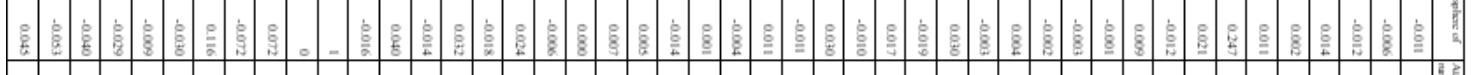

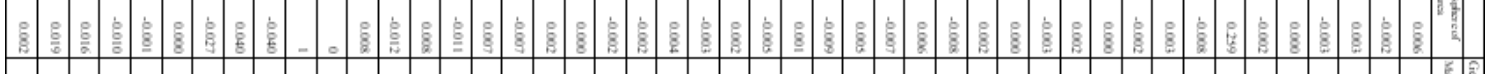

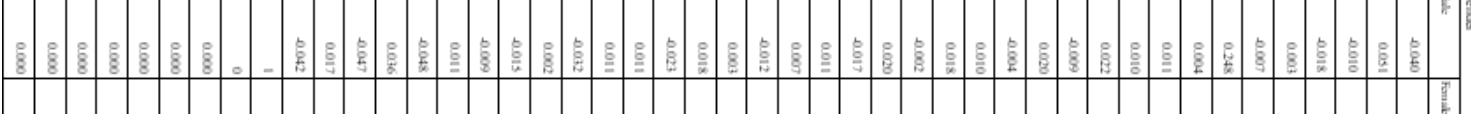

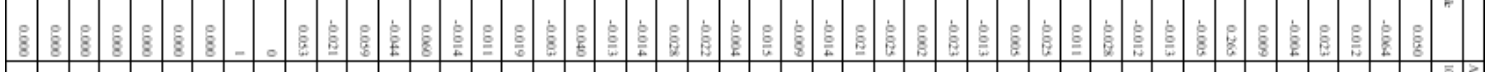

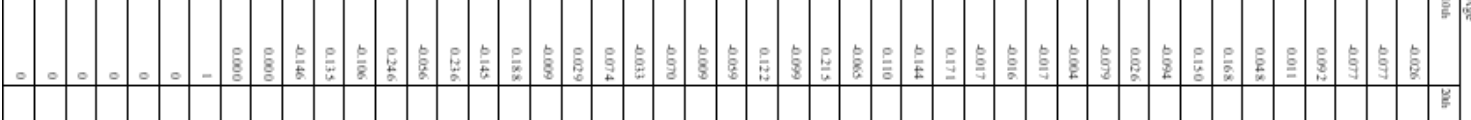

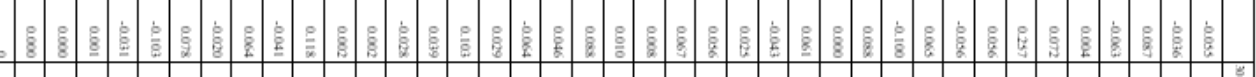

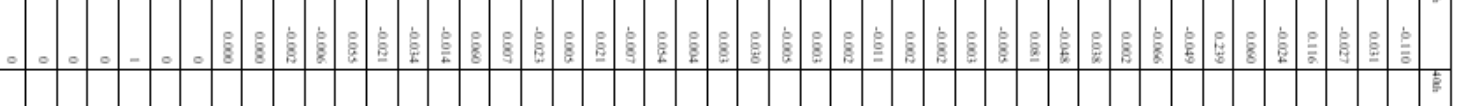

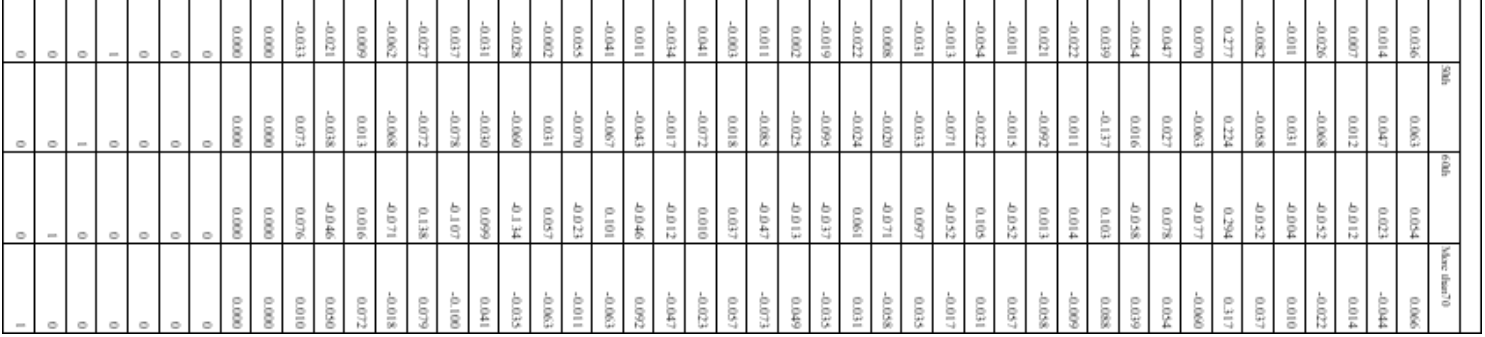

